\title{
Influence of the Magnetic Properties of Slave Media on Perpendicular Duplication Characteristics
}

\author{
Y. Sakaguchi, T. Murata, T. Komine, and R. Sugita \\ Ibaraki University, 4-12-1 Nakanarusawa cho, Hitachi, Ibaraki 316-8511, Japan
}

\begin{abstract}
The influence of the coercivity of perpendicular magnetic recording media as slave media on their perpendicular duplication characteristics was investigated by using micromagnetic simulation. It was found that even for slave media with high coercivity, the magnetic patterns are duplicated on the slave media most clearly when duplication field is much the same value as the coercivity. The duplication characteristics improve as the coercivity of the slave media increases, on account of the increase in the gradient of the recording field as the duplication field increases. The fundamental harmonic wave and the distortion of the output waveform also improve as the coercivity of the slave media increases.
\end{abstract}

Key words: perpendicular duplication characteristics, duplication field, coercivity, output waveform

\section{スレーブ媒体の磁気特性が垂直磁気転写特性に及ぼす影響}

\author{
坂口雄一・村田剛史・小峰啓史・杉田龍二
}

茨城大学工学部, 茨城県日立市中成沢町 4-12-1（兵316-8511）

\section{1. はじめに}

近年のハードディスクの高記録密度化・大容量化に伴い, 垂直磁 気記録方式を採用したハードディスクの実用化が始まっている. また, ヘッドの位置情報であるサーボ信号を高速, 高精度かつ安価 に書き込むことができる垂直磁気転写法が研究されている 1, 2). 垂 直磁気転写法には，面内方向に転写磁界を印加するエッジ転写と， 垂直方向に転写磁界を印加するビット転写がある. ビット転写で 記録した場合の再生波形は, 従来のサーボトラックライター記録 における再生波形と類似しているため, 現在の再生信号処理系を そのまま用いることができる. また, 今後の更なるハードディスク の高記録密度化のためには, 保磁力が高い媒体が求められるが，ス レーブ媒体の保磁力が垂直磁気転写特性に及ぼす影響は明らかに なっていない. そこで本研究では, 垂直磁気記録媒体にビット転写 する際に, スレーブ媒体の保磁力が転写特性に及ぼす影響をマイ クロマグネティックシミュレーションにより明らかにした.

\section{2. 計算方法}

ビット転写は, はじめにスレーブ媒体の垂直方向に初期磁界を 印加しスレーブ媒体を DC 消磁する. 次に, スレーブ媒体にマスタ 一媒体を接触させ, 初期磁界と反対向きに転写磁界を印加する.こ れにより，マスター磁生膜接触部では磁界が強められ初期磁化が 反転し, 非接触部では磁界が弱められ初期磁化が保存される. その 結果, マスター媒体のパターンがスレーブ媒体に転写される.

まず, Fig. 1 に示す計算モデルの記録層部に発生する記録磁界分 布を, 3 次元有限要素法により求めた ${ }^{3)}$. マスター媒体は, マスター 磁性膜の幅及ひ磁性膜間隔の等しいパターンが無限に配置されて いるものを想定した. マスター磁性膜は, ビット長 $100 \mathrm{~nm}$, トラ ック幅 $100 \mathrm{~nm}$, 膜厚 $100 \mathrm{~nm}$ とし, 軟磁性裏打ち層 (SUL) の膜 厚を $200 \mathrm{~nm}$ とした. マスター磁生膜及び SUL の飽和磁化をそれ ぞれ 1900 及び $800 \mathrm{emu} / \mathrm{cm}^{3}$ とし，両磁性膜とも透磁率 $\mu$ を 100 , 保磁力を 0 Oe とした.

次に，計算された記録磁界分布を用いて，記録層の磁化状態を マイクロマグネティックシミュレーションにより求めた ${ }^{4}$. 計算領 域は磁性膜パターンが $3 \times 3$ 個含まれる領域を想定し, 面内方向に
マスターパターンが周期的に配置されているとして, 面内周期境 界条件を課した. SUL には記録層の鏡像が現れるものとして, 鏡 像が作る静磁界を考慮した. 記録層は膜厚 $20 \mathrm{~nm}$ として, SULに 接しているとし, $5 \mathrm{~nm} \times 5 \mathrm{~nm} \times 20 \mathrm{~nm}$ の直方体単磁区粒子で構 成されているとした. 各々の粒子において, 飽和磁化を 500 $\mathrm{emu} / \mathrm{cm}^{3}$, 磁化容易軸の配向角度分散の半值幅 $\Delta \theta_{50}$ を $30 \mathrm{deg}$., 粒子間交換結合を $1 \times 10^{-7} \mathrm{erg} / \mathrm{cm}$ とした. 保磁力の影響を調べる ため, 異方性磁界 $H_{\mathrm{k}}$ を変化させた. また, 異方性分散 $\Delta H_{\mathrm{k}}$ は $H_{\mathrm{k}}$ の $10 \%$ とた.

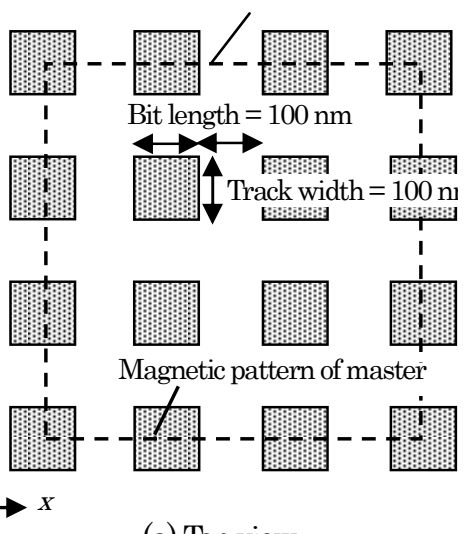

(a) Top view

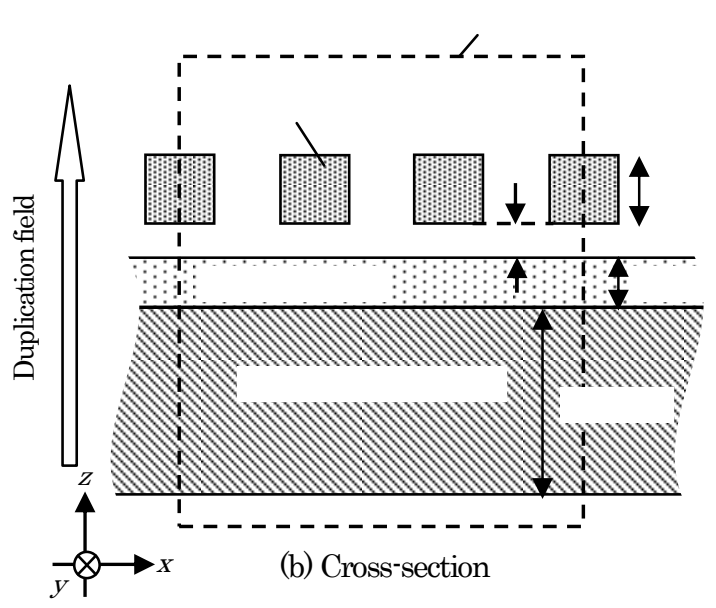

Fig. 1 Calculation model. 
各々の転写特性を評価寸るため, 転写された記録層表面から 10 $\mathrm{nm}$ 離れた場所の洩れ磁界を計算し, トラック幅 $80 \mathrm{~nm}$, 膜厚 5 $\mathrm{nm}$ のフリー層を持つ GMR 素子が記録層とのスペーシング 10 $\mathrm{nm}$ で配置されていると仮定して, フリー層の ABS 面における平 均磁界から出力波形を見積もった. 次に, 出力波形を周波数解析し, 転写状態を評価した.

\section{3. 計算結果と考察}

\section{1 垂直磁化膜のヒステリシスループ}

Fig. 2 に, 異方性磁界 $H_{\mathrm{k}}$ を変化させたときの記録層のヒステリ シスループを示す. 異方性磁界 $H_{\mathrm{k}}$ が大きくなると, 核生成磁界 $H_{\mathrm{n}}$ 及び保磁力 $H_{\mathrm{c}}$ は大きくなるが，ヒステリシスループにおける保磁 力付近の傾き $\alpha\left(\equiv 4 \pi d M /\left.d H\right|_{H=H_{C}}\right)$ はほとんど変わっていない. Fig. 3 に, 核生成磁界 $H_{\mathrm{n}}$, 保磁力 $H_{\mathrm{c}}$, 及び $\alpha$ の異方性磁界依存性 を示す. Fig. 3 から, 異方性磁界 $H_{\mathrm{k}}$ が大きくなると, 核生成磁界 $H_{\mathrm{n}}$ 及び保磁力 $H_{\mathrm{c}}$ が単調に増加することがわかる. 一方, $\alpha$ は約 1.4 と, $H_{\mathrm{k}}$ が変化してもほとんど変化しないことがわかる.

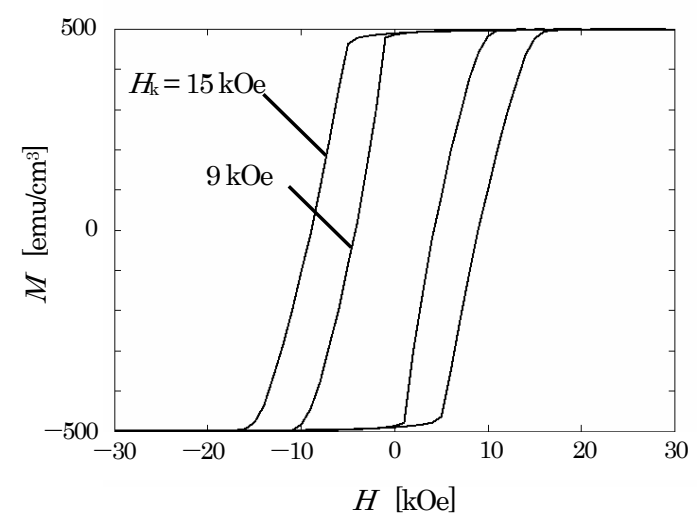

Fig. 2 Hysteresis loops of the recording layer.

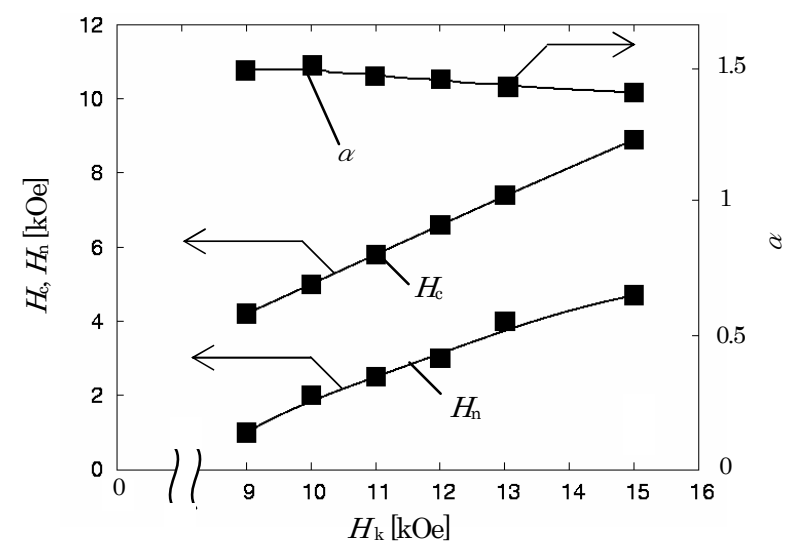

Fig. 3 Anisotropic field dependence of the coercivity $H_{c}$, nucleation field $H_{\mathrm{n}}$, and slope $\alpha$.

\section{2 転写磁界依存性}

スレーブ媒体の保磁力と同程度の転写磁界が最適転写磁界であ ることが以前に報告されている ${ }^{4)}$. 報告されているスレーブ媒体の 保磁力は約 $4 \mathrm{kOe}$ であるため, 保磁力が高いスレーブ媒体におい ても同様の結果が得られるかを検討した. 転写磁界を変化させて
転写した記録層の磁化分布をFig. 4に示寸. 媒体の保磁力は $6 \mathrm{kOe}$ である. Fig. 4 の濃淡は記録層の磁化の垂直成分 $M_{\mathrm{z}}$ を, 飽和磁化 $M_{\mathrm{s}}$ で規格化した值に対応し, 初期磁化 $M_{\mathrm{z}} / M_{\mathrm{s}}$ を一 1 とした. Fig. 4 を見ると，マスター磁性膜接触部では上向きの磁化が転写されて いることがわかる. 保磁力より弱転写磁界を印加したとき, マス タ一磁性膜接触部において磁化反転しない領域が広く存在する. 一方, 保磁力より強い転写磁界を印加すると, 磁生膜非接触部でも 磁化反転がみられ，反転領域がマスターパターンよりも拡大寸る ことがわかる. すなわち, 保磁力と同程度の転写磁界を印加したと きに最も明瞭に転写できていることがわかる. さらに保磁力の高 いスレーブ媒体でも同様の結果を得た.

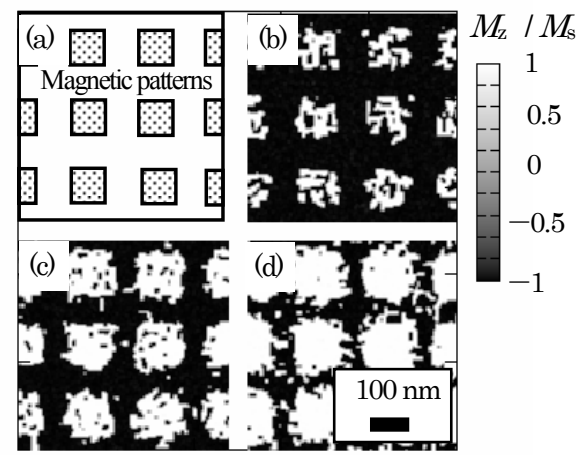

Fig. 4 (a) Alignment of master patterns in the calculation region. Magnetization distributions of the recording layer duplicated with various duplication fields: (b) $4 \mathrm{kOe}$, (c) 6 $\mathrm{kOe}\left(=H_{c}\right)$, and $(\mathrm{d}) 8 \mathrm{kOe}$.

\section{3 保磁力か転写状態に及ぼす影響}

Fig. 5 に, 保磁力 $H_{\mathrm{c}}$ を変化させて転写した記録層の磁化分布を 示す. 転写磁界はそれぞれのスレーブ媒体の保磁力と同程度に設 定した. Fig. 5 を見ると, 保磁力が低い媒体では, マスター磁牲膜 接触部において磁化反転しない部分が島状に存在するのに対し， 保磁力が高い媒体では, 明瞭に転写されていることがわかる.

保磁力が高い媒体において明膫に転写できる理由を考察するた め, 記録磁界分布を調べた. 転写磁界印加時のマスターのトラック 中央部における記録磁界の垂直成分 $H_{\mathrm{z}}$ 分布をFig. 6 に示す. Fig. 6 から, マスター磁生膜接触部では記録磁界が強くなり, 非接触部で は弱くなっていることがわかる. また, 転写磁界 $4 \mathrm{kOe}$ の場合に比 べ, $9 \mathrm{kOe}$ の方が, 磁性膜端部における磁界勾配が大きいことがわ かる. そこで, 記録磁界分布の最大值と最小值の差を $\Delta H$ とし， $\Delta$ $H$ の転写磁界依存性を Fig. 7 に示寸. Fig. 7 から, 転写磁界が強く なるにつれ $\Delta H$ が大きくなることがわかる. これは転写磁界を強 くすることにより，マスター接触部及び非接触部における転写さ れた磁化の差が大きくなることに対応する. また, 転写磁界が 8 $\mathrm{kOe}$ を越えると $\Delta H$ は飽和寸る傾向にあるが, これはマスター磁 性膜の磁化の飽和が原因である. 3.1 節で述べたように，ヒステリ シスループの傾き $\alpha$ はほぼ同じであるので, $\Delta H$ が大きいほうが ヒステリシスループにおける磁化の差が大きくなる. 従って, 転写 の際に強い転写磁界の印加が必要な, 保磁力の高いスレーブ媒体 のほうが明瞭に転写できたと考えられる. 
Magnetic pattern of master

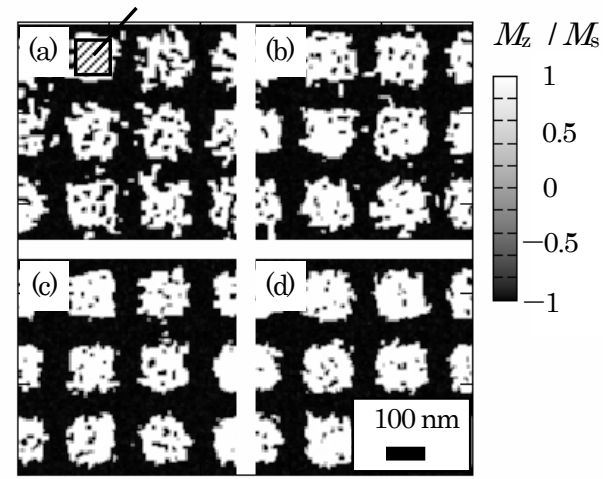

Fig. 5 Magnetization distributions of the recording layer with various coercivities: (a) $4 \mathrm{kOe}$, (b) $6 \mathrm{kOe}$, (c) $7 \mathrm{kOe}$, and (d) $9 \mathrm{kOe}$.

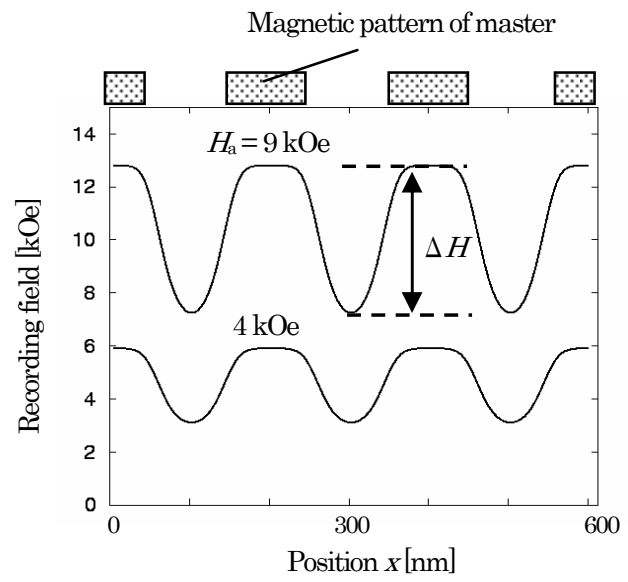

Fig. 6 Recording field distributions along the center of the track.

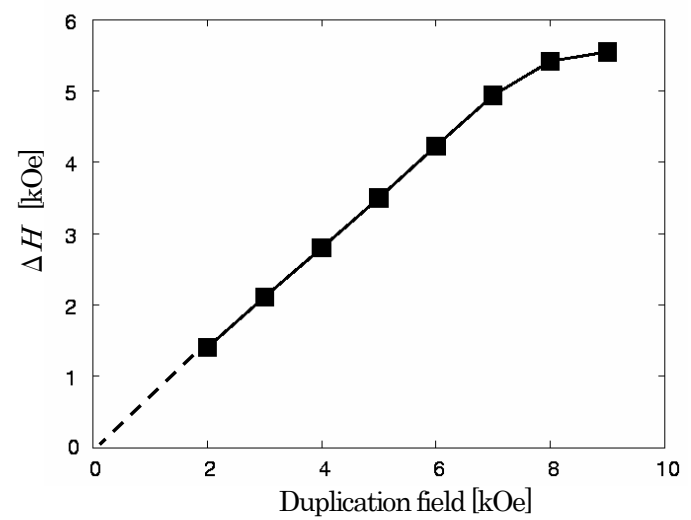

Fig. 7 Duplication field dependence in the difference of the recording field $\Delta H$.

\section{4 出力波形の保磁力依存性}

記録層からの洩れ磁界分布を用いてオントラック時の出力波形 を計算した. 保磁力を変えて転写した記録層からのオントラック 時における出力波形を Fig. 8 に示寸. Fig. 8 から, 保磁力 4 kOe の ときにはパターン接触部で出力波形の歪みがみられるが, 保磁力 が高くなるにつれ歪みが減り，出力波形が矩形波に近づくことが わかる。
次に, 保磁力 $6 \mathrm{kOe}$ の出力波形をフーリエ変換したスペクトル を Fig. 9 に示寸. Fig. 9 から, 直流成分が存在していることがわか る. 直流成分は, トラック間の初期磁化からの洩れ磁界により発生 する. スペクトルの各成分の保磁力依存性を Fig. 10 に示寸. また, ビット長及びトラック幅が $100 \mathrm{~nm}$ で理想的に記録されている記 録層からの出力波形のスペクトルをあわせて図中に示した. Fig. 10 を見ると, 直流及び基本波成分は保磁力が高くなるにつれ理想 状態に近づくが, 第 2 , 第 3 次高調波は理想状態に近づかないこと がわかる.これは, 反転領域がマスターパターンよりも拡大したた めであり，理想状態に近いスペクトルを得るためには反転領域の 拡大を考慮したマスターパターンの設計が必要であることが示唆 される.

Fig. 9 における直流, 基本波及び高調波成分以外はビット中心に おける出力波形の歪夕成分であり, 基本波と歪夕の比はサーボ信 号品質に関係すると考えられる. 基本波を $A 3$, 歪为成分 $B$ を, $B=\sqrt{A_{1}^{2}+A_{2}^{2}+A_{4}^{2}+A_{5}^{2}+\cdots}$ と定義し, $A_{3} / B$ の保磁力依存性を Fig. 11 に示寸. Fig. 11 から, 保磁力が高くなるに伴い $A_{3} / B$ の值 が高くなっていることがわかる. これは, スレーブ媒体の保磁力が 高くなると, 出力波形の基本波成分が大きくなり, 歪み成分が改善 されるためである. このことからも, 保磁力が高いスレーブ媒体に おいて転写特性が改善されていることがわかる。

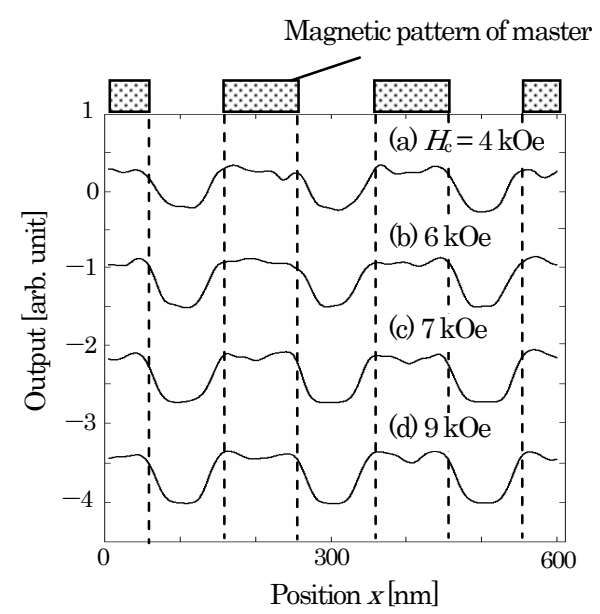

Fig. 8 Output waveforms from duplicated slave media with various coercivities: (a) $4 \mathrm{kOe}$, (b) $6 \mathrm{kOe}$, (c) $7 \mathrm{kOe}$, and (d) 9 $\mathrm{kOe}$.

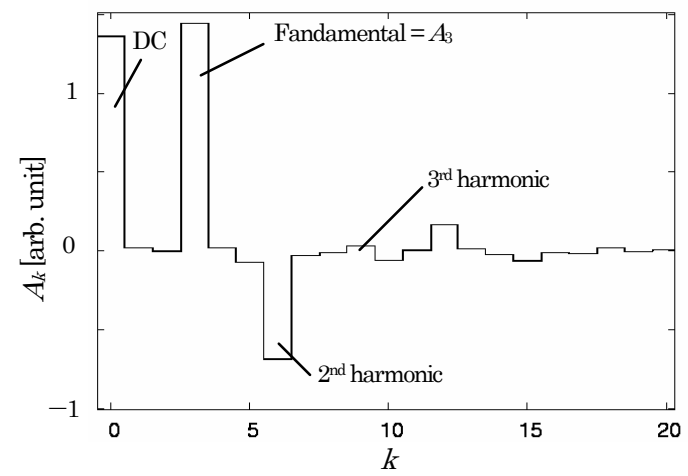

Fig. 9 Spectrum of the output waveform from a duplicated slave medium with a coercivity of $6 \mathrm{kOe}$, which corresponds to Fig. 5 (b) and Fig. 8(b). 


\section{4. まとめ}

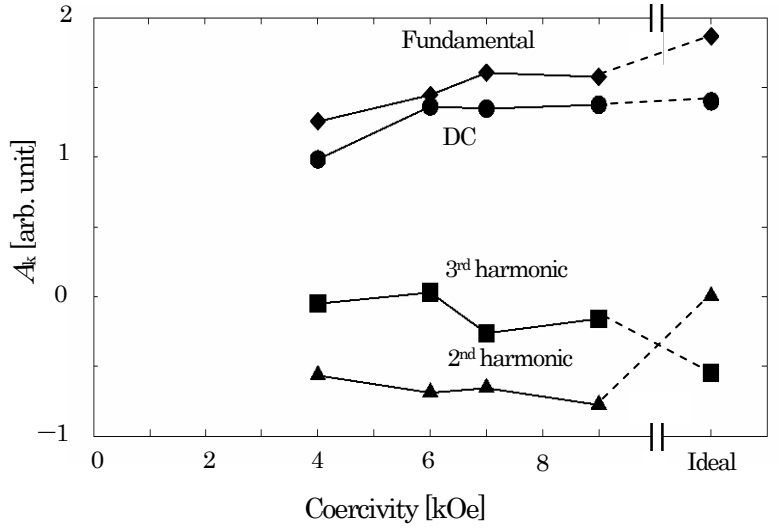

Fig. 10 Coercivity dependence of the dc component, fundamental, $2^{\text {nd }}$ harmonic, and $3^{\text {rd }}$ harmonic waves calculated from output waveforms.

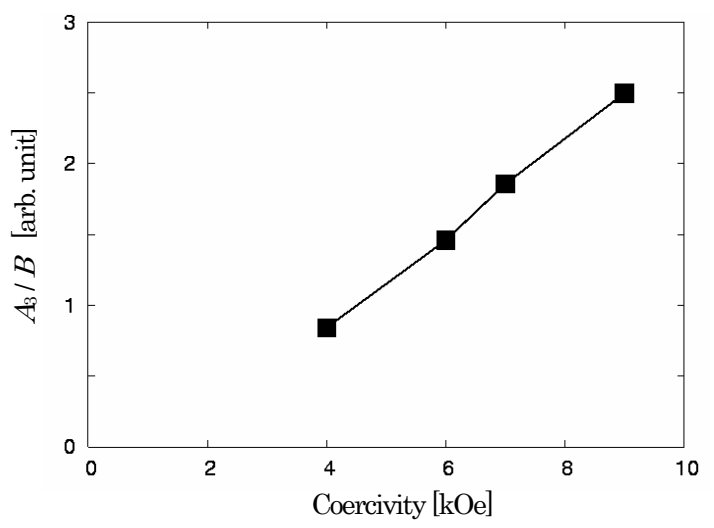

Fig. 11 Coercivity dependence of the output waveform quality.
スレーブ媒体の保磁力が垂直磁気転写特性に及ぼす影響をマイ クロマグネティックシミュレーションを用いて検討した. その結 果, 以下のことがわかった.

- 保磁力が高い媒体においても, 保磁力と同程度の磁界が最 適転写磁界である.

・ 保磁力が高いスレーブ媒体のほうが明瞭に転写できる.こ れは転写磁界が強くなると，記録磁界勾配を大きくできる ためである.

・ スレーブ媒体の保磁力が高くなると, 出力波形の歪みが減 り矩形波に近づくも, 反転領域がマスターパターンより拡 大寸る現象がみられた。

今後, スレーブ媒体の保磁力が垂直磁気転写特性に及ぼす影響 を実験的に検討寸る予定である.

謝辞 本研究の一部は, 新エネルギー・産業技術総合開発機構 (NEDO) 平成 19 年度産業技術研究助成事業の支援により行われ ました. また, 富士フイルム侏の皆様にご協力, ご議論を頂きまし た.ここに深謝いたします.

\section{References}

1) A. Saito, T. Ono and S. Takenoiri: IEEE Trans. Magn., 39, 2234 (2003). 2) M. Nishikawa, S. Wakamatsu, K. Ichikawa, T. Usa, M. Nagao, T. Ishioka, T. Yasunaga, T. Komine and R. Sugita: IEEE Trans. Magn., 42, 2612 (2006).

3) A. Izumi, Y. Nagahama, T. Komine and R. Sugita: J. Magn. Soc. Jpn., 30, 184 (2006)

4) T. Komine, A. Izumi, T. Murata, and R. Sugita: J. Magn. Soc. Jpn., 31, 173 (2007)

2007年10月4日受理，2008年2月14日採録 